Research paper

\title{
Using model forests as a form of balanced forestry in Ukraine
}

\section{Larysa Cherchyk*, Liubov Korchynska and Vitalina Babenko}

Cherchyk, L., Korchynska, L., Babenko, V. 2019. Using model forests as a form of balanced forestry in Ukraine. - Forestry studies | Metsanduslikud Uurimused 71, 69-85, ISSN 14069954. Journal homepage: http://mi.emu.ee/forestry.studies

\begin{abstract}
The relevance of the research topic is prompted by the need to improve the practical instruments of forest management and make them in line with the principles of sustainable development. The research is aimed at facilitating the implementation of environmental, social and economic functions of forest ecosystems in a long-term perspective. The study made use of the following methods: systemic structural analysis, clustering and comparative analysis to identify groups of administrative areas that correspond to certain strategic areas of sustainable forestry. The research is based on cybernetic modeling which helps determining the strategic zones of sustainable forestry. The stages of creating model forests were defined alongside formulating economic, organizational, social and environmental aspects of forest management. The methodology envisages grouping of administrative districts on the basis of a number of factors, including the percentage of forest land, social and economic indicators prompted. The methodology was implemented when analysing official data from several administrative districts in the Zhytomyr region. Several scenarios of sustainable forestry were detailed for each group of administrative districts. Three strategic options were pursued: 1) preserving the viability of forest ecosystems in Ukraine, 2) contributing to the welfare of Ukrainians, 3) ensuring economic development of the forestry sector. It follows from the research that the model forest is a powerful form of cost-effective business interaction in the process of sustainable development that shall bring into action the conservation of nature, provision of comfortable living conditions for territorial communities as well as the most capital-productive utilization of forest resources.
\end{abstract}

Key words: forestry, sustainable development, scenarios of sustainable forestry, strategies of forest area development.

Authors' addresses: Lesya Ukrainka Eastern European National University, Volya Avenue 13, 43025, Lutsk, Ukraine. *e-mail: cherchyk.larysa@eenu.edu.ua

\section{Statement of the problem}

Most of the current socio-economic and environmental challenges are due to the crisis of relations in the system "society nature". To a large extent, this applies to the forestry sector developmental problems which are of great interest through- out the world. Excessive anthropogenic environmental stress leads to global negative changes (climate change, lack of clean water, air, and ecologically safe food, degradation of ecosystems) (Binkley \& van Kooten, 1994; Toman \& Ashton, 1996). This affects the welfare and living conditions of people, their health and develop- 
mental opportunities (Strange et al., 2019; Loehle et al., 2002). Therefore, it is increasingly necessary to accumulate the intellectual efforts of mankind to form a new paradigm of its existence under conditions of non-antagonistic self-development and co-existence with the surrounding world, subordination of economic interests to the interests of environmental feasibility and social responsibility (Hann et al., 2001; Bissix \& Rees, 2001).

Forestry in Ukraine has some signs of ecological, social and economic destabilization. The discrepancy between the existing business practices and the legal rules governing the use of forest resources and land, the application of inefficient forms and methods of forestry led to some negative processes in this area (Cherchyk et al., 2019; Furdychko \& Lavrov, 2009; Angelstam et al., 2017).

The scope of the problem was analyzed in the work of many scientists, however so far, no synthesis of conceptual approaches based on the theoretical platform of sustainable development in forest management has been achieved. By far and large, there is a need for further implementation of effective methods of forest management.

The purpose of the study is to further develop modeling approaches to ensure a balanced forest use. Research objectives are: 1) rationing for the general problem and the starting position of the study; 2) a synthesis of scientific approaches to the application of model forests; 3 ) development of methodological approaches for using model forests in Ukraine; 4) determination of strategic zones of balanced forest management of wooded areas in the Zhytomyr region of Ukraine; 5) development of scenarios of balanced forest management and development directions in administrative regions of the Zhytomyr region of Ukraine.

The informational bases of the study include scientific publications on the research problem, results of generalizations and observations, and statistical materials.

\section{Materials and Methods}

The concept of environmental quality management formulated by L. Cherchyk is the theoretical and methodological basis of this research. According to the author, environmental quality management is a set of principles, methods, means, forms and tools for managing the use of environmental elements in order to ensure environmental safety, increase productivity and efficiency, their recoil and the formation of a model of the future state (Cherchyk, 2016).

The formation of model forests should be based on the following principles: unity and optimal correlation in the system "society - nature"; ecological orientation of economic activity, balanced development of ecosystems; complex use of natural potential while taking into account the ability of ecosystems to self-heal; the priority of public interests over private ones; consideration of balance between environmental, social, and economic constraints or the proportionality of the development of social and natural systems; prevention of degradation of ecosystems.

Indicators of the level of economic efficiency, environmental and social security, and liveliness may be criteria for the effectiveness of the formation and functioning of model forests (Hann et al., 2001); proper level of environmental consciousness and responsibility of citizens (Binkley \& van Kooten, 1994); environmental friendliness of production; conservation of self-improving properties of the forest, optimal structure of afforestation, level of infrastructure development of the territory; non-exhaustive use of wood resources, which does not reduce the area of forests, nor their qualitative composition (Toman \& Ashton, 1996); preservation of the main ecosystem functions of the forest (Synyakevych, 2014; Furdychko \& Lavrov, 2009); provision of the needs of the population in the main types of forest products (places for tourism and recreation, mushrooms and berries, 
clean water and fresh air) (Strange et al., 2019); conservation of biodiversity (Loehle et al., 2002); ecological and economic safety of forestry enterprises (Cherchyk et al., 2019).

The study made use of the following methods: systematic structural analysis and synthesis to determine the methodological elements of formation of model forests; cognitive analysis to balance the objectives of stakeholders; statistical grouping and benchmarking to identify groups of administrative regions that meet certain strategic zones of balanced forest use; cybernetic simulation to determine the strategic zones of balanced forest use. The informational bases of the study include scientific publications on the research problem, the results of generalizations and observations, and statistical materials.

\section{Justification of the general problem and the starting position of the study (1)}

A study of the scientific work of many scientists and the application of the method of systemic structural analysis and synthesis allowed us to conclude that the experiences of forming model forests are quite diverse. The main aim of creating model forests is to ensure the sustainable development of the community on a territory. In our opinion, the preconditions for the formation of model forests are in the conceptual aspects of ecologization and sustainable forest management. In particular, Synyakiewicz (2014) defines the notion of ecologization of social development as an objective process of counteraction to global ecological threats in the ecological, economic, social and spiritual spheres, transformation of consumers' destructive mentality of people into the natural and economical tools - into environmental policy tools. These scientists define ecologization of economic activity in forestry as "the process of working out forest policy (especially principles and tools), which provides ecological sta- bility and high productivity of forest ecosystems, effective use of forest resources."

Furdychko \& Lavrov (2009) consider "the balance of forest use ... as ensuring interdependent compliance with economic efficiency, environmental safety and social acceptability".

For a better understanding of the essence of sustainable forest management, a number of European conferences were held in Helsinki (1993), Lisbon (1998), and Vienna (2003). The criteria and indicators for balanced forest management were developed and adopted.

Today, the establishment of a common forest management policy is being carried out in Europe through the Ministerial Conferences on Forest Protection in Europe, with the participation of those responsible for forest management. In particular, at the Sixth Ministerial Conference on the Protection of Forests in Europe in Oslo in 2011, the vision of the main purpose of forests in Europe was formulated and the strategic objectives of forest management in European countries until 2020 (Oslo Ministerial Decision, 2011) were formulated.

According to the European vector, all forests in Europe should be viable, productive and multifunctional. At the same time, people's well-being, a healthy environment and economic development in Europe and the rest of the world should be guaranteed. The unique potential of forests to support the green economy, livelihood, mitigation of global warming, biodiversity conservation, water quality and anti-desertification needs to be preserved (Forest Strategy, 2011).

The World Community has identified objectives for sustainable forest management in Europe: ensuring the multi-use of forest resources and other forest products and services as renewable natural resources; adapting to climate change, ensuring forest sustainability to natural disasters and protection from threats of anthropogenic origin, such as forest fires; increasing the productivity of forest plantations and 
their protective functions; raising the potential of forests to mitigate the effects of global warming through the deposition of carbon in timber and soil; replacing non-renewable material and energy resources with forest resources without disturbing the global carbon balance; stopping the loss of biodiversity, restoring degraded forest plantations; strengthening the socio-economic and cultural benefits of the forest, especially those relating to the well-being of the rural population; eliminating illegal logging and illegally harvested timber in Europe (Forest Strategy, 2011).

The experience of developed countries in working out strategic documents on state and regional levels shows that the forest management strategy is effective if it is consistent with all stakeholders, therefore the theory of stacking has become widespread, the essence of which is reduced to the fact that the maximum consideration of the position of the interested persons at the time of adopting managerial decisions makes it possible to minimize possible risks in the future (Yarova, 2010; Ostrom, 2012; Krasnokutska, 2014).

In particular, Yarova (2010) defines ecologically balanced forest management as the implementation of mechanisms and tools for ecologically and socially responsible forest management, which will facilitate the resolution of ecological and economic contradictions and conflicts that arise in the processes of use and reproduction of forest resources between existing forestry departments and enterprises as well as harmonization of relations between stakeholders.

The role of local communities is also emphasised by international standards for responsible forestry, the standards of social responsibility that require economic operators in the use, protection and reproduction of forest resources to coordinate their actions with communities, provide them with access to forest resources, and maintain their traditional rights in the field of forestry.
In the developed countries, the practice of using forests for environmental and social needs has become commonplace. The importance of forests in ensuring the development of green economy and the social sphere is increasing. At the same time, the role of public institutions that are tangential to the use, restoration and preservation of forests is growing. Unofficial factors such as the ecological consciousness of the citizens of the country, their culture, traditions and customs, and spirituality are becoming a priority among the levers that influence the processes of developing forest management strategies.

\section{A synthesis of scientific approaches to using model forests (2)}

The idea of constructing model forests appeared in the early 1990s under the influence of the adoption of national and international commitments in the field of sustainable forest management (Angelstam et al., 2019; Kuzmynov, 2009). This idea combines the efforts of individuals and organizations that support the concept of sustainable partner management of forests. By attracting new supporters, each model forest contributes to the implementation of balanced forest management in its territory. Projects of model forests cover such areas as water resources; climate change and carbon dioxide deposition; traditional environmental information; methods of forestry management; socio-economic sphere; wildlife environment and more. The concept of model forests serves as an instrument for the implementation of sustainable forest management on an ecological and economic basis. It covers the economic, social and environmental aspects of social life.

The experience of forming model forests is quite diverse. Depending on the purpose of their creation, the main ones are: sustainable development of the community of territory $-16 \%$, innovative prac- 
tices and instruments - 14\%, biodiversity conservation $-11 \%$, education $-11 \%$, use of non-wood forest products $-8 \%$. Indigenous peoples' involvement in cooperation $-7 \%$, protection of water and soil $-7 \%$, adaptation to climate change $-6 \%$, ecosystem services $-6 \%$, ecological tourism development $-6 \%$, bioenergetics $-4.5 \%$ (Kuzmynov, 2009).

In our opinion, the purpose of creating model forests is the formation of effective interaction of stakeholders in the sustainable development of a territory on the basis of jointly developed procedures and rules within the framework of the current legislation, which will allow the implementation of environmental functions, provide the population of this territory with comfortable living conditions, ensure the most efficient and productive use of all forest resources, without degrading the forest ecosystem.

The practice of functioning model forests in many countries of the world confirms the effectiveness of this form of realizing the long-term goals of developing forests and territorial communities, achieving positive results from a number of projects that underlie the formation of model forests (Angelstam et al., 2019; Kuzmynov, 2009).

In accordance with the principles and criteria outlined above, the main goals of the formation of model forests are:

- creating conditions for the transition to sustainable development;

- consistency of interests of the main stakeholders;

- ecological recovery and reproduction of disturbed forest ecosystems;

- preservation and expansion of biological and landscape diversity;

- formation and development of corporate systems of ecological management of forest enterprises;

- application of a strategic approach as the basis for the development of model forests;

- formation of an effective system of informational and analytical support of model forests for the production of new knowledge and environmental education.

Consequently, the model forest is a kind of a unique forum, where participants have an opportunity to not only discuss different views and share their work experience, but also to combine their knowledge and resources to develop and implement new approaches to balanced forest management, which takes into account the features of a specific region. At the same time the model serves as a huge laboratory in which the development, implementation and monitoring of the most advanced methods and technologies of forest management can be analyzed.

A required prerequisite is taking into account the potential of the forest to meet the projected needs of future generations; the protection of water, air, soil, the forest ecosystem in general; reducing or preventing the negative impacts of human activities on the forest ecosystem.

The determining factor is that the model forest should be developed by groups of stakeholders who are interested in balanced forest management. These groups should include representatives of different social strata, united by the understanding of the inevitability of environmental, economic and social losses in using forest resources in traditional ways. Typically, in the process of creating model forests, diverse alternative approaches, plans, projects, shared goals and joint plans for achieving them should be discussed. Employees of the institutions that are part of model forests are the initiators of innovative solutions to the issues of balanced forest management. The decision on the management of model forests is developed by coordinating the interests of all stakeholders, public discussion and approval by both executive authorities and public institutions.

These principles, criteria, goals and fundamental provisions of sustainable forest- 
ry functioning can be successfully implemented in the conditions of the formation of model forests in the regions of Ukraine.

\section{Methodological approaches to forming model forests in Ukraine (3)}

The formation of model forests, in our opinion, involves the following steps:

1) creating an appropriate institutional environment, taking into account international practice (formation of a regulatory framework, development of procedures and rules, development of a system of organizational support, and motivation for achieving balanced forest use);

2) monitoring and analyzing indicators of the current condition of model forests;

3) diagnostics of the condition of model forests in accordance with strategic goals;

4) forecasting the main characteristics of the development of model forests;

5) selection of a strategy and strategic planning for the development of model forests;

6) selection of tools for meeting goals and the implementation of the strategy;

7) organizational support for the implementation of strategic plans;

It is important to note that in each region a community can be formed that determines the content and form of the regional model forest. The following groups of people should be involved in the development of model forests: scientists who explore the processes of forest use; teachers, post-graduate and graduate students of forestry departments; teachers and students of rural schools located in the areas where the forest is located; managers of forest enterprises; residents of rural territories; members of green public and political organizations; consumers of forest prod- ucts; suppliers and business partners.

Model forest projects must take into account the economic, organizational, social and environmental aspects of forestry management. The economic aspect is to ensure economic sustainability of the forest complex, to improve the system of forest payments, to apply effective organizational forms of forest management, to create mechanisms for accounting for mutual economic interests of forest owners, forest harvesters, state authorities and local self-government, the introduction of ecologically oriented technologies and methods of forestry and forest management, etc.

The social aspect is to involve the local population in the process of forest management decision-making, forestry problem-solving; provision of recreational needs; informing about the principles of sustainable forest management.

The ecological aspect includes the support and provision of ecological functions of forests, in particular, the conservation of biodiversity, the study of the impact of forest management on the state of forests and the sustainability of forest ecosystems, in particular, the protection of water resources and soils; development and application of the landscape planning method. The organizational aspect is seen as the formation of mechanisms for sustainable forest management and improvement of the forestry planning system. To do this, criteria and indicators of sustainable forest management need to be introduced. The normative basis for forestry planning and forestry management has to be developed. Informational systems of forestry and forest management on the basis of geoinformation systems should be introduced. A single information system of model forests needs to be created; programs and projects developed, and the centres for dual education founded (Synyakevych, 2014). 
Selecting the strategic zones for balanced forest management in districts of the Zhytomyr region in Ukraine (4)

In order to create a conceptual platform for the development of a model forest, a methodology for determining strategic zones of balanced forest management has been developed and tested with the help of a case-study of some administrative districts of the Zhytomyr region. The selection of zones was carried out in a certain sequence. The first step was to group the administrative districts by forest coverage (Table 1, Figure 1).

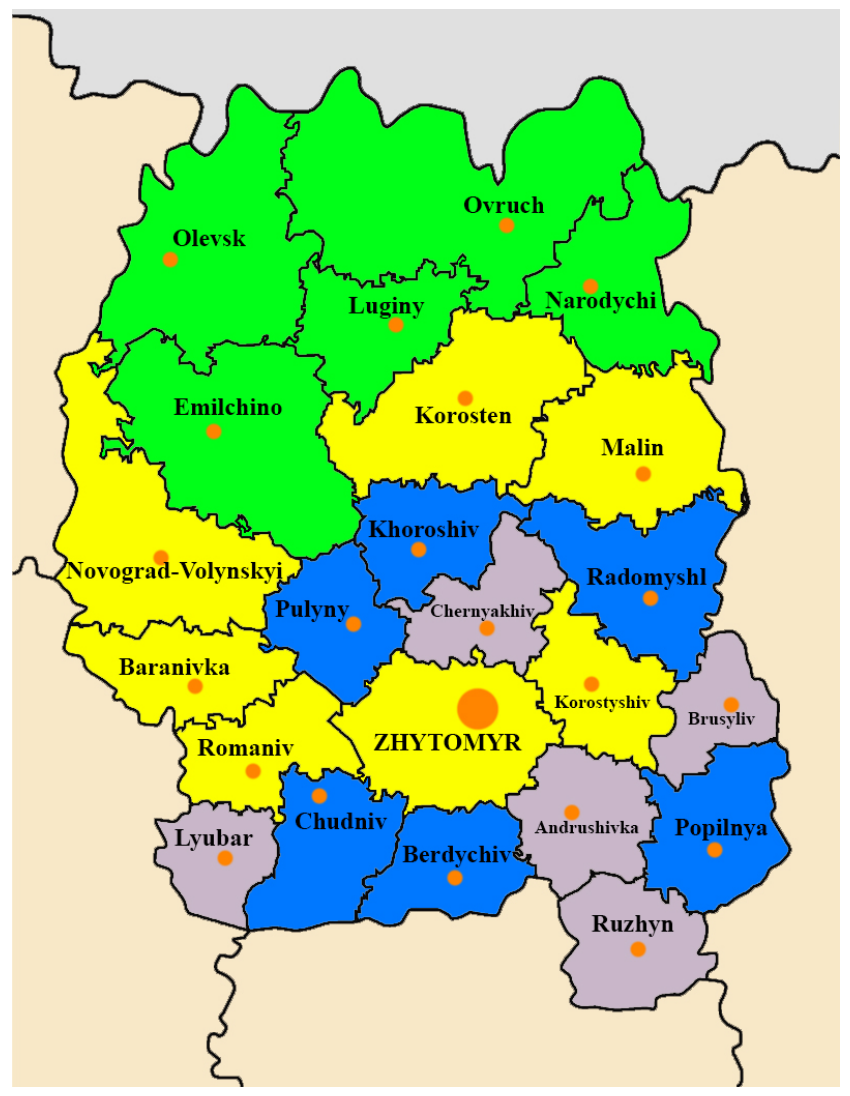

Figure 1. Map of groups of administrative districts of Zhytomyr region according to forest coverage.

Table 1. Groups of administrative districts of the Zhytomyr region by forest coverage.

\begin{tabular}{ll}
\hline $\begin{array}{l}\text { Groups of districts according } \\
\text { to forest coverage, \% }\end{array}$ & Name of administrative districts \\
\hline $40.1-70.0$ (I group) & $\begin{array}{l}\text { Olevsky, Ovrutsky, Luginsky, Narodytsky, Emilchinsky } \\
\text { Baranivsky, Korostyshivsky, Malinsky, Novograd-Volynskyi, Romanivsky, } \\
\text { Korostensky, Zhytomyrsky } \\
\text { Radomyshlsky, Khoroshivsky, Pulynsky, Chudnivsky, Berdychivsky, }\end{array}$ \\
$10.1-29.0$ (III group) & $\begin{array}{l}\text { Popilnyansky } \\
\text { Andrushivsky, Brusylivsky, Chernyakhivsky, Lyubarsky, and Ruzhynsky }\end{array}$ \\
$5.0-10.0$ (IV group) &
\end{tabular}


If we take into account only the forest coverage of an administrative area, then we could propose the following areas of forest management: for Group IV - forest management, which is aimed at utilizing the useful properties of forests (preferably with secondary forest management); for Group III - forest management, which is characterized by indirect forest use (preferably using the useful properties of forests); for Group II - forest management, based on which timber harvesting (preferably with lateral forest use) should be laid; for Group I - forest management associated with the harvesting of wood (preferably with hunting).

An important aspect in the distribution was compliance with the regulatory norms provided by the "Procedure for the division of forests into categories and the allocation of specially protected forests" (Government of Ukraine, 2007). The results of the previous formation of zones of balanced forest use for their forest potential are given in Table 2 .

The next step in defining strategic zones is an analysis of the social and economic development of administrative regions. The analysis of statistical data characterizing the social development of districts differentiated by forest coverage, economic development of districts, and indicators of forest management.

Definition of such indicators is necessary for clarification of the scenarios of balanced forest use for each group of districts. If we take into account the proposed

Table 2. Balanced forest use for groups and administrative districts by their forestry potential in the Zhytomyr region.

\begin{tabular}{|c|c|c|c|c|c|}
\hline \multirow[t]{2}{*}{ Group } & \multirow[t]{2}{*}{ District } & \multicolumn{4}{|c|}{ Type of forest use } \\
\hline & & $\begin{array}{c}\text { Timber } \\
\text { harvesting }\end{array}$ & $\begin{array}{l}\text { Non-wood forest } \\
\text { products }\end{array}$ & $\begin{array}{c}\text { Forest ecosystem } \\
\text { services }\end{array}$ & Hunting \\
\hline \multirow[t]{5}{*}{ I } & Olevsky & घ & + & + & $\bullet$ \\
\hline & Ovrutsky & - & + & + & - \\
\hline & Luginsky & - & + & + & - \\
\hline & Narodytsky & - & + & + & - \\
\hline & Emilchinsky & a & • & + & - \\
\hline \multirow[t]{7}{*}{ II } & Baranivsky & - & • & + & - \\
\hline & Korostyshivsky & - & - & + & - \\
\hline & Malinsky & - & $\bullet$ & + & $\bullet$ \\
\hline & Novograd-Volynskyi & - & $\bullet$ & + & $\bullet$ \\
\hline & Romanivsky & - & - & + & $\bullet$ \\
\hline & Korostensky & - & $\bullet$ & + & - \\
\hline & Zhytomyrsky & - & $\bullet$ & + & $\bullet$ \\
\hline \multirow[t]{6}{*}{ III } & Radomyshlsky & - & - & + & $\bullet$ \\
\hline & Khoroshivsky & + & - & $\bullet$ & $\bullet$ \\
\hline & Pulynsky & + & - & - & $\bullet$ \\
\hline & Chudnivsky & + & - & - & - \\
\hline & Berdychivsky & + & - & $\bullet$ & $\bullet$ \\
\hline & Poplinsky & + & - & $\bullet$ & $\bullet$ \\
\hline \multirow[t]{5}{*}{ IV } & Andrushivsky & + & $\bullet$ & - & $\bullet$ \\
\hline & Brusylivsky & + & $\bullet$ & - & $\bullet$ \\
\hline & Chernyakhivsky & + & $\bullet$ & - & $\bullet$ \\
\hline & Lyubarsky & + & - & - & $\bullet$ \\
\hline & Ruzhynsky & + & - & - & - \\
\hline
\end{tabular}

Note: the development of sustainable forest management:

- - prevailing; + - desirable; $\quad$ - supporting. 
Table 3. Main economic and social indicators of the Zhytomyr region according to the official statistics of 2018 (Office of Statistics, 2019a).

\begin{tabular}{|c|c|c|c|c|c|}
\hline $\begin{array}{l}\text { Administrative } \\
\text { districts }\end{array}$ & $\begin{array}{l}\text { Number of } \\
\text { enterprises }\end{array}$ & $\begin{array}{l}\text { Number of } \\
\text { employees, } \\
\text { thousand people }\end{array}$ & $\begin{array}{c}\text { Average } \\
\text { salary, UAH/ } \\
\text { month }\end{array}$ & $\begin{array}{c}\text { Sales, million } \\
\text { UAH }\end{array}$ & $\begin{array}{c}\text { Population, } \\
\text { thousand } \\
\text { people }\end{array}$ \\
\hline Olevsky & 1415 & 4.4 & 6812 & 1037.3 & 41.1 \\
\hline Ovrutsky & 1849 & 7.4 & 6577 & 2175.0 & 54.8 \\
\hline Luginsky & 367 & 1.3 & 6710 & 227.5 & 16.0 \\
\hline Narodytsky & 163 & 0.8 & 6928 & - & 9.5 \\
\hline Emilchinsky & 814 & 3.7 & 6647 & 1205.2 & 32.2 \\
\hline Group I total & 4608 & 17.6 & & 4645 & 153.6 \\
\hline Share, \% & 9.3 & 8.8 & & 4.3 & 12.6 \\
\hline Baranivsky & 1031 & 4.1 & 7000 & 1201.0 & 39.1 \\
\hline Korostyshivsky & 2421 & 6.9 & 6587 & 960.4 & 39.8 \\
\hline Malinsky & 428 & 2.8 & 10111 & 2174.5 & 18.4 \\
\hline Novograd-Volynskyi & 836 & 6.1 & 7755 & 5958.4 & 44.4 \\
\hline Romanivsky & 894 & 3.1 & 3207 & 981.5 & 27.7 \\
\hline Korostensky & 501 & 4.5 & 8772 & - & 25.7 \\
\hline Zhytomyrsky & 2735 & 15.6 & 8814 & 6516.3 & 71.9 \\
\hline Group II total & 8846 & 43.1 & & 17792.1 & 267.0 \\
\hline Share, $\%$ & 17.9 & 21.6 & & 16.4 & 21.9 \\
\hline Radomyshlsky & 1186 & 3.9 & 8074 & 3405.5 & 36.6 \\
\hline Khoroshivsky & 1002 & 4.0 & 7446 & 1680.9 & 34.3 \\
\hline Pulynsky & 537 & 1.5 & 6732 & 751.2 & 22.5 \\
\hline Chudnivsky & 855 & 2.7 & 7312 & 1079.9 & 33.7 \\
\hline Berdychivsky & 769 & 2.8 & 7133 & 989.8 & 28.0 \\
\hline Poplinsky & 1166 & 4.5 & 8146 & 3140.7 & 30.6 \\
\hline Group III total & 5515 & 19.4 & & 11048.0 & 185.7 \\
\hline Share, \% & 11.2 & 9.7 & & 10.2 & 15.2 \\
\hline Andrushivsky & 941 & 3.6 & 7384 & 2304.9 & 32.6 \\
\hline Brusylivsky & 513 & 2.2 & 6295 & 1003.2 & 14.7 \\
\hline Chernyakhivsky & 835 & 2.9 & 6955 & 970.8 & 27.9 \\
\hline Lyubarsky & 823 & 2.7 & 6636 & 1520.6 & 26.4 \\
\hline Ruzhynsky & 801 & 2.3 & 5977 & 1228.8 & 26.1 \\
\hline Group IV total & 3913 & 13.7 & & 7028.3 & 127.7 \\
\hline Share, $\%$ & 7.9 & 6.9 & & 6.5 & 10.5 \\
\hline All over the area & 49366 & 199.5 & 7949 & 108572 & 1220.2 \\
\hline
\end{tabular}


Table 4. Forestry indicators of the Zhytomyr region according to the official statistics of 2018 (0ffice of Statistics, 2019b).

\begin{tabular}{|c|c|c|c|c|c|}
\hline $\begin{array}{l}\text { Administrative } \\
\text { districts }\end{array}$ & Area, $\mathrm{km}^{2}$ & Afforestation, \% & $\begin{array}{l}\text { Production } \\
\text { volumes, } \\
\text { million UAH }\end{array}$ & $\begin{array}{l}\text { Supply } \\
\text { of wood, } \\
\text { thousand } \mathrm{m}^{3}\end{array}$ & $\begin{array}{l}\text { Reproduction } \\
\text { of forests, ha }\end{array}$ \\
\hline Olevsky & 2247 & 64.9 & 201.8 & 367.3 & 1122 \\
\hline Ovrutsky & 3221 & 62.1 & 333.6 & 545.8 & 1472 \\
\hline Luginsky & 994 & 49.6 & 91.4 & 151.0 & 358 \\
\hline Narodytsky & 1284 & 45.8 & 53.9 & 89.0 & 296 \\
\hline Emilchinsky & 2112 & 41.9 & 108.1 & 196.8 & 474 \\
\hline Group I total & 9858 & 55.0 & 788.8 & 1349.9 & 3722 \\
\hline Share, $\%$ & 33.1 & & 39.8 & 38.7 & 44.0 \\
\hline Baranivsky & 1000 & 37.0 & 113.3 & 175.1 & 460 \\
\hline Korostyshivsky & 974 & 35.4 & 109.1 & 198.2 & 534 \\
\hline Malinsky & 1467 & 34.6 & 249.2 & 306.2 & 439 \\
\hline Novograd-Volynskyi & 2098 & 33.9 & 216.9 & 360.8 & 832 \\
\hline Romanivsky & 928 & 32.0 & 41.5 & 76.7 & 269 \\
\hline Korostensky & 1735 & 30.8 & 127.1 & 196.4 & 639 \\
\hline Zhytomyrsky & 1441 & 29.6 & 111.2 & 196.6 & 302 \\
\hline Group II total & 9643 & 33.2 & 968.3 & 1510.0 & 3475 \\
\hline Share, \% & 32.3 & & 48.8 & 43.3 & 41.1 \\
\hline Radomyshlsky & 1297 & 28.8 & 70.6 & 240.5 & 466 \\
\hline Khoroshivsky & 870 & 22.4 & 34.0 & 84.5 & 174 \\
\hline Pulynsky & 853 & 18.4 & 33.8 & 84.1 & 167 \\
\hline Chudnivsky & 1037 & 13.7 & 0.9 & 3.4 & 9 \\
\hline Berdychivsky & 865 & 11.6 & 33.9 & 84.4 & 173 \\
\hline Poplinsky & 1037 & 10.4 & 48.6 & 120.5 & 258 \\
\hline Group III total & 5959 & 10.4 & 221.8 & 617.4 & 1247 \\
\hline Share, $\%$ & 20.0 & & 11.2 & 17.7 & 14.7 \\
\hline Andrushivsky & 956 & 8.6 & 1.5 & 3.9 & 4 \\
\hline Brusylivsky & 626 & 8.5 & 0.8 & 3.4 & 3 \\
\hline Chernyakhivsky & 850 & 7.3 & 0.8 & 2.1 & 3 \\
\hline Lyubarsky & 757 & 6.5 & 0.3 & 0.8 & 1 \\
\hline Ruzhynsky & 1002 & 6.5 & 0.3 & 1.0 & 6 \\
\hline Group IV total & 4191 & 6.6 & 3.7 & 11.2 & 17 \\
\hline Share, $\%$ & 14.1 & & 0.2 & 0.3 & 0.2 \\
\hline All over the area & 29827 & 33.6 & 1982.6 & 3488.5 & 8461 \\
\hline
\end{tabular}


strategic goals, namely option 1 "Preserving the viability of the forests of Ukraine", option 2 "Maintaining the welfare of the people of Ukraine", option 3 "Ensuring economic development of forestry", then it is logical to recommend for each strategic goal option different scenarios of socio-economic development of each group of districts, depending on the existing level of forest cover and their socio-economic status.

The next step in identifying strategic areas is to analyse the social and economic status of the administrative areas (Table 3). Forestry indicators are shown in Table 4.

Statistics show the following:

- $\quad$ the I group of districts is characterized by the highest index of afforestation (45.1-70.0\%), volumes of products and services of forestry $(39.8 \%$ of the total indicator in the region), logging (38.7\% of the total indicator in the region), forest reproduction (44\%); predominance of primary forest management; the heterogeneity of virtually all indicators that determine the social and economic status; the share of the population in the region as a whole $-12.6 \%$, workers $-8.8 \%$; sales volumes $-4.3 \%$. In this group of districts, two defining factors are the level of afforestation and forestry indicators. These areas are characterized by an increased level of radioactive contamination in large areas;

- the II group of districts is characterized by average forest cover (29.6-37\%), slightly lower indicators of forestry products and services ( $48.8 \%$ of the total indicator in the oblast), and that of the harvesting of timber $(43.3 \%)$ than the total indicator in the oblast), forest reproduction $(36.3 \%)$; predominance of primary forest management; indicators of the social and economic status between the regions differ significantly, but are much higher than in the regions of group I, especially population density and volumes of sales; the share of the population in the region as a whole $-21.9 \%$, workers $-21.6 \%$; sales volume $-16.4 \%$; in this group of districts, two determinants of development are the level of forest cover and population;

- the III group of districts is characterized by an index of forest cover from 10.6 to $28 \%$, low volumes of products and services of forestry $(11.2 \%$ of the total indicator in the region), logging $(17.7 \%$ of the total indicator in the region), forest reproduction (24\%); predominance of side forestry; indicators of the social and economic status in the regions are heterogeneous, higher than in the regions of group I, lower than in the districts of group II; sufficiently high population density, volumes of sales; the share of the population in the region $-15.2 \%$, workers $-9.7 \%$; sales volumes $-10.2 \%$; in this group of districts, two determinants of development are population and economic activity;

low forest cover (6.6-8.6\%), timber harvesting $(0.2 \%$ of the total indicator in the region) is characteristic of the IV group of districts; predominance of utilization of beneficial properties of forests; indicators of the social and economic status of this group of districts are more homogeneous, but the lowest, although the population density is quite high; the share of the population of the total in the region $-10.5 \%$, workers $-6.9 \%$; sales volume $-6.5 \%$. Summarizing these trends, it can be argued that the forestry industry in this group of districts does not affect the welfare of the population, social infrastructure and economic development of the districts. For them, agriculture is more decisive. 


\section{Balanced forest management scenarios and directions of development of districts of the Zhytomyr region of Ukraine (5)}

Since the situation in the first and fourth groups of districts is fundamentally different, we will propose balanced development scenarios.

The following strategic objectives are substantiated: 1. "Sustaining the forestry of Ukraine", 2. "Maintaining the well-being of the people of Ukraine", 3. "Ensuring economic development of Ukrainian forestry". Each of these objectives requires different scenarios of socio-economic development of each group of districts, depending on the existing level of forest cover and their socio-economic status.

Taking into account the above-mentioned aspects, it is possible to recommend the following development directions for the I group of districts according to:

- option 1 "Preservation of the viability of the forests of Ukraine" - limited use of useful properties of forests, limited management of hunting and limited forbidden forest use (only in territories with indicators of radioactive contamination within acceptable limits). This approach will allow forest ecosystems to connect radioactive elements, terminating their migration. For the social and economic support of this group of districts, the development of targeted programs aimed at the development of local industries, tourism development (in the territories with indicators of radioactive contamination within acceptable limits) and other types of economic activities not related to forestry activities are needed;

- option 2 "Maintaining the welfare of the people of Ukraine" - transformation of the distribution of financial resources coming from forest use in favour of the local community in whose territory the felling of forests is taking place. However, the use of such fi- nancial resources should only be in the form of social programs aimed at maintaining the well-being of the local population. Currently, fees for the use of forest resources are distributed among the state, oblast and local budgets. But the use of these funds is not always aimed at maintaining local communities and, moreover, at restoring forest resources;

- option 3 "Ensuring economic development of the forestry sector of Ukraine" - forest management related to the harvesting of wood. However, it should be noted that such a variant of the strategic goal in the long term will lead to a reduction in the volumes of forest products and timber, the export potential of the forestry sector, the decline of the social and economic level of both the population and the region as a whole.

Analysis of the indicators of the development of a group of areas with the lowest forest coverage, defined as group IV (Andrushivsky, Brusilivsky, Chernyakhivskyy, Lyubarsky, Ruzhynsky), suggests that the level of social and economic development in these regions is approximately the same.

If we compare the indicators of social and economic development in the districts of this group with the indicators for the group of areas with the highest forest coverage (Group I), then it is obvious that:

- the population density in areas of group IV is almost twice as high as that of group I; however, the number of settlements is almost twice as small;

- the number of pre-school educational institutions and their children in the I and IV groups of districts is almost identical, however, the number of children and general education institutions in group IV is significantly lower than in group I;

- the share of libraries, clubs, hotels in group IV is significantly lower than in group I; 
- the number of business entities, the volume of sales of goods, the volume of imports of goods and services, the volume of agricultural products, the volume of capital investment and wholesale trade by regions in group IV, significantly exceed the similar indicators of the regions included in group I;

- $\quad$ in areas of group IV, the volumes of products, work and services in forestry as well as the harvesting of liquid wood are insignificant; the reproduction of forests is virtually non-existent. The generalization of the above tendencies suggests that the forestry sector in this group of regions does not affect the welfare of the population, social infrastructure and economic development of the districts. The agriculture sector is more dominant.

Taking into account the foregoing, it is logical to recommend for the districts of group IV other directions of development, namely for:

- option 1 "Preservation of the viability of the forests of Ukraine" - development and implementation of programs for the reproduction of forests, especially in enterprises united by the ZhOKAP "Zhytomiroblagrolis" system. Such an approach in the end will allow the preservation of forest ecosystems to future generations and reduce the negative environmental impact of agricultural enterprises on the environment. For the social and economic support of the population of this group of districts, a redistribution of financial resources from the use of agricultural land for the benefit of the local community is necessary;

- option 2 "Maintaining the welfare of the people of Ukraine" - development and implementation of programs aimed at supporting the interests of the local population, sometimes at the expense of the agricultural sector;

- option 3 "Ensuring economic development of the forestry sector of Ukraine"
- this option in the short term is not implemented for this group of districts.

The proposed development directions can be supplemented by a SWOT analysis performed for each administrative region separately. But it is important to emphasize that even taking into account the social and economic status of administrative districts when grouped according to forest coverage, this significantly corrects previous recommendations for the formation of strategic zones of balanced forest management. The expediency of a comprehensive consideration of all factors that influence the processes of achieving sustainable forest management can be achieved through the creation of a model forest in each group of districts, or each administrative district.

The developed scenarios for strategic zones of balanced forest use should be used in panel discussions in the model forest format.

\section{Discussion}

The analysis of systematic studies on the implementation of sustainable forest policy has shown that many scientists are considering a landscape approach, which combines both the socio-economic context of modern forest management and ecological context, which includes the protection, reproduction and cultivation of forests, ensuring their implementation, ecosystem functions, assimilation potential, and biodiversity conservation.

In particular, Toman \& Ashton (1996), considering the forest resources and the sustainability of ecosystems from environmental and economic prospects, note that despite the sustainability of forest ecosystems, they are producers of valuable goods and services for the community. Therefore, it is worth considering the issue of sustainable forest management in two contexts: "as economic efficiency and stability may differ in its consequences for forest management, and as criteria for sustainability 
of the forest system are related to the scale of management decisions (for example, individual forest areas relative to the region or world biosphere)". Binkley \& van Kooten (1994) grounded the need for economic and ecological assessment of forests in the context of the integration of climate change and forests. They considered the need for an effective policy to address the expected climate change in the context of bilateral interaction between climate, forests and society.

Note that these studies should be considered as pioneer studies, which laid the foundations of sustainable forest development, and judging by the numerous quotes, received both support and development. Agreeing with the fundamental positions of these scientists, the authors of the article emphasize the formation of acceptable environmental, social and economic aspects of the human environment (the concept of environmental management) with the priority of global and strategic functions of the forest.

Strange et al. (2019), studying the problem of afforestation of unproductive agricultural lands, see a real option in the joint production of environmental services, forest products and environmental products such as biodiversity, hunting, water supply, carbon sequestration, recreation.

Loehle et al. (2002), examining landscape management issues, see it as an instrument for solving common forest management problems with non-financial objectives.

Hann et al. (2001) emphasize the possibilities of integrated management in solving landscape protection problems, which allows biodiversity to be preserved, landscapes restored, and jobs to be created for this.

Bissix \& Rees (2001), wondering if strategic management of ecosystems can succeed in a multi-agent environment, note that in Nova Scotia, Canada, "market dis- tortions and inertia in a multi-agent political economy are too powerful and widespread to allow successful implementation management of ecosystems in the long run". Therefore, it is necessary to apply a system of incentives for shifting from production to preservation, taking into account the various interests and values of numerous stakeholder groups.

Angelstam et al. (2019) analysed the results and implications of initiatives using the international model forest. They concluded that the policy of sustainable forest management is rather ambiguous and a comprehensive landscape approach can help. In addition, in order to develop regionally adapted approaches to the implementation of the policy of sustainable forest development, it is necessary to exchange experience in the creation and operation of model forests and other concepts of the landscape approach between countries and regions. The authors proposed a general analytical basis for learning based on the evaluation of long-term initiatives, the experience of sustainable forest development and cross-sectoral multi-level governance.

The need for knowledge generation and training for sustainable forest management is justified in the work of Angelstam et al. (2017).

In contrast to the positions of the abovementioned authors, we consider the possibility of applying a landscape approach on the basis of balanced forest use and the interaction of all its potential counterparts in the context of the formation of model forests as a modern format for solving both current and strategic problems of the development of the territory, taking into account the administrative division. The above does not contradict the developed positions, but places emphasis on the other, developing theoretical, methodological and applied aspects of sustainable forest use in the model forest model. 


\section{Conclusions}

The review of scientific sources confirms the position of the authors regarding the impossibility of further application of modern domestic approaches in the management of forestry and the feasibility of transition to sustainable development in the Zhytomyr region, Ukraine. One progressive approach that meets the principles of sustainable development is the landscape planning, where the experience of creating model forests has expanded.

The generalization of existing experience and results of scientific research allowed identifying the preconditions for the transition to sustainable forest management on the internationally agreed principles, according to strategic objectives of forest management in many European countries, and a Pan-European approach of formation of national forest programs.

The theoretical and methodological basis of the research includes the concept of environmental quality management, on the basis of which principles, criteria of efficiency, goals and main objectives of the formation and functioning of model forests are defined.

The essence of the model forest as a unique forum in which participants are able to combine knowledge, resources, experience for research in the field of forestry, introduction of new methods of balanced forest management, taking into account their own and public interests and features of a particular region.

An important prerequisite for the implementation of balanced forest management is the establishment of a consensus among stakeholders: forestry enterprises, forest products consumers, territorial communities, forest management authorities, environmental protection organizations, etc. It is advisable to coordinate the multi-vector of interests of all interested persons with the help of an information platform, which will function as a forum for creating a model forest. This approach will contribute to strengthening the role of society, in particular, of the territorial communities, in the process of using, restoring and preserving the forests of Ukraine.

The methodology for determining the strategic zones of balanced forest management, which involves the grouping of administrative districts by forest coverage, the formation of zones of balanced forest use for their forest potential, indicators of forest management based on data on the social and economic development of districts differentiated by the forest coverage, is developed. Based on these indicators, the scenarios of balanced forest use for each group of districts are specified according to the following strategic goals for Ukraine: 1) preservation of the viability of forests; 2) maintenance of the welfare of the people; and 3) ensuring the economic development of the forestry sector.

The methodology is tested on the example of administrative regions of the Zhytomyr region. For each group of districts, depending on forest coverage and the socio-economic status, different development scenarios are recommended for each option of the strategic goals. The developed scenarios for strategic zones of balanced forest use should be used for discussion when substantiating the model forest format.

Acknowledgements. The research is carried out in accordance with the topic of scientific research of the Lesia Ukrainka Eastern European National University "Socio-Ecological and Economic Security Management" (state registration number 0117U002302). 


\section{References}

Angelstam, P., Naumov, V., Elbakidze, M. 2017. Transitioning from Soviet wood mining to sustainable forest management by intensification: are tree growth rates different in northwest Russia and Sweden? - Forestry, 90, 292-303. https://doi.org/10.1093/ forestry/cpw055.

Angelstam, P., Elbakidze, M., Axelsson, R., Khoroshev, A., Pedroli, B., Tysiachniouk, M., Zabubenin, E. 2019. Model forests in Russia as landscape approach: Demonstration projects or initiatives for learning towards sustainable forest management? Forest Policy and Economics, 101, 96-110. https://doi.org/10.1016/j.forpol.2019.01.005.

Binkley, C.S., van Kooten, G.C. 1994. Integrating climatic change and forests: Economic and ecologic assessments. - Climatic Change, 28, 91-110. https://doi.org/10.1007/BF01094102.

Bissix, G., Rees, J.A. 2001. Can strategic ecosystem management succeed in multiagency environments? - Ecological Applications, 11, 570-583.

Cherchyk, L., Shershun, M., Khumarova, N., Mykytyn, T., Cherchyk, A. 2019. Assessment of forest enterprises' performance: integrating economic security and ecological impact. Entrepreneurship and Sustainability Issues, 6(4), 1784-1797. http://doi.org/10.9770/ jesi.2019.6.4(17).

Cherchyk L.M. 2016. Management of environmental quality. (Менеджмент якості навколишнього середовища). - Economic Innovations, 61, 377-383. (In Ukrainian).

Forest Strategy. 2011. Forest strategy 2020. Sustainableforestmanagement-anopportunity and a challenge for society. Federal Ministry of Food, Agriculture and Consumer Protection. 36 pp. [WWW document]. - URL http:// www.bmel.de/SharedDocs/Downloads / EN/Publications/ForestStrategy2020.pdf? blob=publicationFile. [Accessed 3 January 2020].

Furdychko O.I., Lavrov V.V. 2009. Forestry of Ukraine in the Context of Sustainable Development: Theoretical and Methodological, Regulatory and Organizational Aspects. (Лісова галузь України у контексті сталого розвитку: теоретико-методологічні, нормативно-правові та організаційні аспекти). Kiev, Basis. 424 pp. (In Ukrainian).

Government of Ukraine. 2007.Procedure of division of forests in the category and allocation of especially protective forests, approved by the decision of the Cabinet of Ministers of Ukraine № 733 of May 16, 2007. (Порядок поділу лісів на категорії та виділення особливо захисних лісових ділянок, затверджений постановою Кабінету Міністрів України № 733 від 16 травня 2007 р.).
Hann, W.J., Hemstrom, M.A., Haynes, R.W., Clifford, J.L., Gravenmier, R.A. 2001. Costs and effectiveness of multi-scale integrated management. - Forest Ecology and Management, 153(1-3). 127-145. http://doi. org/10.1016/S0378-1127(01)00457-1.

Krasnokutska, N.S. 2014. Theory of Stakeholders: the main provisions and areas of research. (Теорія зацікавлених сторін: основні положення та сфери дослідження). Krasnokutska N.S., Ryshkova Ya.S. (eds.). Economic Strategy and Prospects for the Development of Trade and Services. (Економічна стратегія i перспективи розвитку сфери торгівлі та послуг). Kharkiv, XDUXT 1, 96-104. (In Ukrainian).

Kuzmynov, Y. 2009. Model forests: history of development and themes of projects. (Модельные леса: история развития и тематика проектов). - Sustainable Forest Management, 2(21), 17-20.

Loehle, C., MacCracken, J.G., Runde, D., Hicks, L. 2002. Forest management at landscape scales: solving the problems. - Journal of Forestry, 100(6), 25-33.

Office of Statistics. 2019a. Business Performance Indicators for Regional Cities and Districts in 2018. Official Website of the General Directorate of Statistics in Zhytomyr Oblast. (Показники діяльності підприємств по містах обласного значення та районах у 2018 році: офіційний веб-сайт Головного управління статистики у Житомирській області). [WWW document]. - URL http:// www.zt.ukrstat.gov.ua/StatInfo/Pidpr/ pidprrai.htm. [Accessed 20 December 2019]. (In Ukrainian).

Office of Statistics. 2019b. Main indicators for the use and protection of forests and animal resources: the official website of the Main Directorate of Statistics in Zhytomyr Oblast. (Основні показники використання й охорони лісу, тваринних ресурсів: офіційний веб-сайт Головного управління статистики у Житомирській області). [WWW document]. - URL http://www. zt.ukrstat.gov.ua/StatInfo/Sered/lis.htm. [Accessed 20 December 2019]. (In Ukrainian).

Oslo Ministerial Decision. 2011. Oslo ministerial decision: European forests 2020. [WWW document]. - URL http://www.foresteurope. org/docs/ELM/2011/FORESTEUROPE_ MinisterialConference_Oslo2011_ EuropeanForests2020.pdf. [Accessed 3 January 2020].

Ostrom, E. 2012. Management of the Common. Evolution of Collective Action Institutions. (Керування спільним. Еволюція інституцій колективної діiі). Kiev, Nash Chas. 398 pp. (In Ukrainian). 
Strange, N., Jacobsen, J.B., Thorsen, B.J. 2019. Afforestation as a real option with joint production of environmental services. - Forest Policy and Economics, 104, 146-156. http:// doi.org/10.1016/j.forpol.2019.04.015.

Synyakevych, I.M. 2014. Ecology of Forest Use in the Context of Overcoming Global Environmental Threats. (Екологізація лісокористування в контексті подолання глобальних екологічних загроз). Lviv, Kamula. 592 pp. (In Ukrainian).
Toman, M.A., Ashton, P.M.S. 1996. Sustainable forest ecosystems and management: A review article. - Forest Science, 42(3), 366-377.

Yarova, I.Ye. 2010. Organizational-economic principles of environmental management of forest management. (Організаційноекономічні засади екологізації управління лісовим господарством). - The Mechanism of Regulation of the Economy, 3(1), 227-236. (In Ukrainian). 